\title{
Implementation of Education Management on Leading Class Program
}

\author{
Candra Wijaya1, Budi², Zulkhairi3, Mulkan Hasibuan4, Edy Rosadi5
}

DOI: $10.35445 /$ alishlah.v13i1. 416

\begin{tabular}{l}
\hline Article Info \\
\hline Keywords: \\
Educational \\
Management \\
Leading Class Program
\end{tabular}

\begin{abstract}
This study aims to determine the planning, organization, implementation, monitoring, and evaluation of superior class education programs at MTsN 2 Medan. This study uses a qualitative method. This type of qualitative method used is naturalistic interactive, namely research on natural reciprocal relationships. Based on this qualitative approach, according to the researcher, it is very relevant because it aims to find out how the implementation of superior class program education management at MTs N 2 Medan. There are five findings in this study after data reduction/exposure is carried out, namely: the superior class program planning is the policy of the Head of the Regional Office of the Ministry of Religion. Second, organizing superior classes is carried out by establishing/holding an exceptional coordinator, a superior class program coordinator. Third, the implementation of the addition of subjects related to and the addition of tutoring. Fourth, supervision of the superior class program at MTs N 2 Medan was carried out by cooperating with the principal of the madrasah and the superior class coordinator. The last, the evaluation of the flagship class program is carried out (once a month) by tutoring in collaboration with the madrasah.
\end{abstract}

\begin{abstract}
Abstrak
Tujuan penelitian ini adalah untuk mengetahui perencanaan, pengorganisasian,
\end{abstract}

Kata kunci:

Manajemen Pendidikan Program Kelas

Unggulan

\footnotetext{
${ }^{1}$ Pascasarjana UIN Sumatera Utara, Medan, Indonesia

Email: candrawijaya@uinsu.ac.id

2 Pascasarjana UIN Sumatera Utara, Medan, Indonesia

Email: budi.0334203028@uinsu.ac.id

3 Pascasarjana UIN Sumatera Utara, Medan, Indonesia

Email: zulkhairi@iainlhokseumawe.ac.id

4 Pascasarjana UIN Sumatera Utara, Medan, Indonesia

Email: mulkan.hasibuan@uinsu.ac.id

5 Pascasarjana UIN Sumatera Utara, Medan, Indonesia

Email: edy.rosadi@uinsu.ac.id
} 
di MTs N 2 Medan dilakukan dengan bekerja sama dengan kepala madrasah dan koordinator kelas unggulan. Temuan Kelima, evaluasi program kelas unggulan dilakukan (sebulan sekali) dengan bimbingan belajar bekerja sama dengan madrasah.

\section{PENDAHULUAN}

Manajemen pendidikan memegang peranan yang sangat penting dalam mencapai tujuan pembelajaran. Kurangnya pemahaman dari guru terhadap praktek yang sesuai manajemen pendidikan adalah suatu hal yang tidak dapat ditutupi. Hal ini jelas terlihat dari sedikitnya bahkan tidak terlihatnya penerapan manajemen pendidikan dalam menjalankan proses belajar mengajar. Bentuk konkritnya dapat dilihat dari sikap guru itu sendiri dalam kesehariannya, padahal dalam ajaran Islam ada iman dan moral yang harus dipedomani.

Di Indonesia, telah banyak sekolah-sekolah yang menerapkan manajemen pendidikan seperti sekolah Islam terpadu yang berkembang pesat di Kota Medan dalam dasawarsa pertama abad ke-21. Jumlah Sekolah Islam Terpadu (SIT) yang tergabung dalam JSIT saat ini lebih dari 200 sekolah se-Indonesia dan 100 diantaranya dari jenjang TK. Di Sumatera Utara, terdapat 30 TK, 14 SD, 2 SMP, dan 1 SMA yang tersebar di hampir setiap kabupaten. Untuk Kabupaten Deli Serdang terdapat $6 \mathrm{TK}, 3 \mathrm{SD}, 1 \mathrm{SMP}$.

Lawrence A. Apply dan Oey Liang Lee (2010:16) berpendapat bahwa sebagai seni dan ilmu, dalam manajemen terdapat strategi memanfaatkan tenaga dan pikiran orang lain untuk melaksanakan aktivitas yang diarahkan pada pencapaian tujuan yang telah ditentukan sebelumnya. Dalam manajemen terdapat teknik-teknik yang kaya dengan nilai-nilai kepemimpinan dalam mengarahkan, mempengaruhi, mengawasi, dan mengorganisasikan semua komponen yang saling menunjang untuk tercapainya tujuan.

Peran manajemen dalam pelaksanaan di ruang lingkup pendidikan itu sangatlah penting dalam pencapaian visi dan misi organisasi. Isu tentang pendidikan adalah mengenai pengembangan sekolah dan membangun budaya mutu/kualitas di sekolah. Para kepala sekolah dan pimpinan terkait perlu waktu untuk membenahi tugas pembelajaran pada organisasi sekolah. Belajar tentang kekuatan dan kelemahan, staf, dan moral, bangunan, peralatan-peralatan yang cukup atau tidaknya, budaya organisasi sekolah, hubungan kemasyarakatan, jaringan, dan alokasi dana atau keuangan sekolah adalah salah satu faktor yang penting perlu dicermati secara sistematik. Faktor yang menentukan reformasi manajemen, khususnya manajemen sekolah adalah ditentukan oleh kualitas kepemimpinan manajer yang dilaksanakan oleh kepemimpinan kepala sekolah. Juga keterlibatan para guru dan anggota staf sekolah pun sangat mendukung dalam penerapan manajemen yang baik yaitu, dalam hal pengambilan keputusan, penguasaan masalah dalam memenuhi peluang perencaan bersama, tujuan perubahan budaya sekolah, berarti menuntut anggota staf mengasumsikan tanggung jawab terhadap perbaikan sekolah dengan kewenangan dan dukungan yang diperlukan untuk menciptakan program pengajaran (instructional program) yang mencapai kebutuhan pendidikan dan pelajar.

Dalam penelitian Kartaningsih dkk. (2014) mendeskripsikan bahwa (1). Perencanaan, pengorganisasian, pelaksanaan dan evaluasi program kelas unggulan Madrasah Tsanawiyah Negeri 2 Pontianak dalam bentuk 12 program perencanaannya yang sistematis, terarah, jelas, realistis, sehingga pelaksanaan program sesuai dengan visi misi madrasah, (2). Penempatan guru dan pegawai serta pendelegasian dan pembagian tugas sesuai dengan bidang keahliannya dan sangat jelas, (3). Evaluasi program kelas unggulan dalam bentuk pelaporan kepada orang tua siswa tentang perkembangan akademik, emosiaonal sikap dan perilaku siswa serta pertanggung jawaban program dan dana telah dilaksanakan dengan baik.

Sebagaimana Penelitian Wati dan Syunu (2020) diketahui bahwa strategi pengelolaan kelas unggulan dalam meningkatkan prestasi belajar siswa ialah dengan membangun kerjasama dengan siswa dalam pembelajaran. Strategi yang kedua adalah dengan menciptakan iklim pembelajaran 
yang kondusif, guru berusaha menciptakan suasana kelas yang aman dan nyaman, adapun strategi dalam mengatasi hambatan berupa fasilitas yang kurang memadai maka guru dan unsur pimpinan sekolah adalah memaksimalkan program pembelajaran dan perlu bimbingan dan arahan pihak orang tua siswa dalam hal kesadaran siswa akan hak dan kewajibannya dalam mengikuti proses belajar mengajar.

Penelitian oleh Hanun (2016) diketahui bahwa Program kelas unggulan yang dilaksanakan pada kelas unggul meliputi; keunggulan akademik, keunggulan moral dan keunggulan skill, masing-masing keunggulan tersebut memiliki program program khusus. Pertama komponen akademik memiliki program berbahasa asing baik bahasa inggris maupun bahasa arab, Kedua program pembentukan moral meliputi; a). Mabit (malam bina iman dan taqwa), b). shohihul ibadah (ibadahnya baik), c). Matimul khuluq (akhlak terpuji). Ketiga komponen skill meliputi; keterampilan rumah tangga, siswa dibekali dengan keterampilan rumah tangga agar kelak menjadi manusia yang berdaya guna dalam masyarakat dan memiliki sikap kepemimpinan.

Berdasarkan observasi di lapangan dalam hal pelaksanaan manajemen pendidikan program kelas unggulan di madrasah ditemukan beberapa hal yang bisa dianggap menarik dan unik di madrasah tersebut. Kurikulum kelas unggulan sama dengan kelas reguler, hanya saja di tambahkan jam pelajarannya, dan ada bimbingan atau les, fasilitas sarana dan Prasarana yang memadai di kelas unggulan Hal ini kurang lebih 85\% berbeda dengan kelas reguler. Adanya program studi banding ke luar daerah dan juga adanya bimbingan-bimbingan yang bersifat religi meliputi, (1). Tilawah Alquran, (2) Tahfiz Alquran, (3) Khataman Alquran, dan (4) Manasik Haji.

Dari keunikan yang diungkapkan di atas, mengingat luas dan kompleksnya permasalahan tentang pelaksanaan manajemen pendidikan, maka pada penelitian ini peneliti membatasi ruang lingkup masalah yang akan diteliti pada aspek pelaksanaan manajemen pendidikan program kelas unggulan yang meliputi perencanaan program pendidikan kelas unggulan, pengorganisasian program kelas unggulan, pelaksanaan program kelas unggulan, pengawasan program kelas unggulan, dan evaluasi program kelas unggulan.

Penelitian ini penting penulis lakukan karena berfokus pada strategi manajemen pendidikan melalui program kelas Unggul yang bertujuan menghasilkan siswa-siswa berprestasi, unggul, mampu bersaing dan bermutu dalam bidang pengetahuan umum, agama dan teknologi.

\section{METODE}

Penelitian ini menggunakan metode kualitatif. Dalam penelitian kualitatif, menurut Bogdan dan Taylor (2012) yang dikutip oleh Moleong, mendefinisikan metodologi kualitatif sebagai prosedur penelitian yang menghasilkan data deskriptif berupa kata-kata tertulis atau lisan dari orang-orang dan perilaku yang dapat diamati. Menurut mereka, pendekatan ini diarahkan pada latar dan individu tersebut secara holistik (utuh). Jadi dalam hal ini tidak boleh mengisolasikan individu atau organisasi ke dalam variabel atau hipotesis, tetapi perlu memandangnya sebagai bagian dari sesuatu keutuhan. Berdasarkan pendekatan kualitatif ini menurut peneliti sangat relevan, karena bertujuan untuk mengetahui bagaimana pelaksanaan manajemen pendidikan program kelas unggulan di MTs N 2 Medan.

Penelitian ini dilakukan dengan cara mengumpulkan data secara berulang ke lokasi penelitian dengan melakukan pencatatan data dan informasi yang dikumpulkan, dikelompokkan, dianalisa kemudian ditemukan, maka dari pelaksanan manajemen pendidikan program kelas unggulan di MTs N 2 Medan. Lokasi penelitian ini dilaksanakan di MTs N 2 Medan terletak di Jalan Peratun Nomor o3 Komplek Medan Estate, kode pos 20371 Medan. Berdekatan dengan Kampus Universitas Terbuka.

Secara komprehensif penelitian ini dilaksanakan dengan beberapa tahapan, mulai dari melakukan observasi awal di lokasi tempat, melakukan pendekatan, pelaksanaan, perencanaan, pengumpulan data dari hasil yang diteliti, hingga penulisan laporan dan evaluasi. Dalam melakukan pengumpulan data, informan atau yang dijadikan sebagai sumber informasi dalam 
penelitian ini adalah: kepala madrasah, wakil kepala madrasah, koordinator kelas unggulan, guru, dan KTU (Kabag. Tata Usaha).

Data yang diperoleh dari lapangan dan hasil pengamatan, wawancara dan penggunaan dokumen pada proses perencanaan, pengorganisasian, pelaksanaan, pengawasan, dan evaluasi pendidikan program kelas unggulan di MTs N 2 Medan. Adapun teknik Pengumpulan data yang digunakan dalam penelitian kualitatif ini meliputi:

a. Wawancara. Adapun interview berupa tanya jawab terhadap informan atau subjek penelitian yang terlibat dalam pengelolaan program kelas unggulan di MTs Negeri 2 Medan yang bertujuan untuk memperoleh informasi-informasi yang objektif dan akurat terkait pelaksanaan program kelas unggulan.

b. Observasi. pelaksanaan observasi merupakan pengamatan langsung untuk memperoleh data-data penelitian. Fokus observasi dalam penelitian ini adalah untuk melihat bagaimana aktivitas program kelas unggulan di MTs N 2 Medan. dalam pelaksanaan observasi ini, dibantu dengan alat rekam dan foto yaitu kamera digital, android aplikasi rekam audiovisual dan media teknologi lainnya. Data-datanya berupa keadaan fisik madrasah, ruang kelas belajar program kelas unggulan, perilaku murid dan guru, interaksi warga madrasah disekitarnya.

c. Studi Dokumen. Studi dokumentasi yang dilaksanakan dalam penelitian ini adalah dengan mengumpulkan bukti-bukti fisik yang otentik berupa arsip atau catatan yang di dapat pada saat melakukan penelitian di madrasah, yang berhubungan dengan pelaksanaan manajemen program kelas unggulan di MTs N 2 Medan.

\section{HASIL PENELITIAN}

\section{Perencanaan Program Kelas Unggulan}

Proses kegiatan belajar mengajar, perencanaan adalah hal yang utama mendapatkan perhatian, sebagaimana hasil wawancara beikut ini:

Berdirinya program kelas unggulan ini disebabkan adanya keinginan Kepala Kantor Wilayah Kementerian Agama yaitu menginginkan adanya kelas unggulan di beberapa madrasah khususnya di Sumatera Utara. Ketika itu ditentukan dan dipilih madrasah mana yang boleh melakukan adanya program madrasah kelas unggulan dan termasuklah MTs N 2 Medan. Kelas unggul ini diadakan agar dapat melihat potensi-potensi atau bakat siswa yang terbaik di sekolah ini, untuk dapat meningkatkan kualitas pendidikan di madrasah dan peningkatan sumber daya manusia (SDM).

Sebagaimana diungkapkan pelaksanaan program kelas unggulan yaitu untuk meningkatkan kualitas siswa dalam proses pendidikan. Agar pihak sekolah mampu melihat kemampuan siswa untuk di didik sehingga terjadinya peningkatan sumber daya manusia terhadap siswanya juga kepada tenaga pengajar (guru).

Berdasarkan deskripsi data di atas dapat disimpulkan bahwasannya lahirnya program kelas unggulan di dasari atas sikap Ka. Kanwil Kementrian Agama Propinsi Sumatera Utara, yang dimana dianggap penting untuk dibentuknya salah satu kelas unggul di Madrasah. Diantara madrasah salah satunya yaitu MTs N 2 Medan.

\section{Pengorganisasian dan Perekrutan Siswa Program Kelas Unggulan}

Pengorganisasian kelas unggulan tidak jauh bedanya dengan kelas reguler, sebagaimana dijelaskan. Struktur pengorganisasian antara kelas unggulan dengan reguler itu hampir sama. Hanya saja di kelas unggulan ada Koordinator kelas unggulan yang langsung di bawah pengawasan kepala madrasah, selain kepala madrasah juga ada tim khusus yang mengkoordinir kelas unggulan tersebut. 
Juga diungkapkan oleh koordinator kelas unggulan bahwa pengorganisasiaan sama dengan reguler, kepala madrasah dan wakil kepala madrasah, dan pada kelas unggulan juga terdapat kordinatornya.

Mengenai perekrutan dan penerimaan siswa kelas unggulan di MTs Negeri 2 Medan, Sebagaimana diungkapkan juga:

1. Harus lulus menjadi siswa MTs $\mathrm{N} 2$ Medan, dengan melalui beberapa test, meliputi: nilai test baca Alquran dan test potensi akademik.

2. Setelah lulus, kemudian melakukan test kembali, yaitu tes IQ yang bekerja sama dengan psikolog dan bimbingan test.

3. Wawancara.

4. Kemudian menentukan apakah siswa tersebut bisa masuk ke dalam kelas unggulan atau tidak dengan mengundang orang tua/wali mereka yang bertujuan untuk membicarakan bahwa di kelas unggul itu memerlukan biaya Sakdiyah P) banyak/tambahan. Agar tidak terjadi penyesalan di kemudian hari.

Juga berdasarkan hasil wawancara dengan salah seorang guru mengatakan bahwa:

Untuk perekrutan siswa kelas unggulan yang pastinya mencari anaknya yang pintar agar bisa menyesuaikan dengan kawan kelasnya maka penting melakukan test akademik. Pihak sekolah juga mencari siswa yang mempunyai mental yang kuat seperti kemauan belajar yang lebih, agar dalam proses pembelajaran pembinaan siswa unggul berjalan sesuai dengan visi dan misi madrasah.

Berdasarkan keterangan diatas dapat disimpulkan bahwasanya pengorganisasian kelas unggulan tidak jauh bedanya dengan kelas reguler, hanya saja di kelas unggulan ada koordinator kelas unggulan. Tapi, tidak terlepas dari tanggung jawab kepala madrasah beberapa WKM (wakil kepala madrasah), KTU, dan lain sebagainya.

\section{Pelaksanaan Program Kelas Unggulan}

Program kelas unggulan pada MTs N 2 Medan harus berjalan sesuai Visi dan Misi yang telah dicanangkan sebelumnya, agar di dalam pelaksanaan proses kegiatan belajar mengajar dapat berlangsung secara efektif dan efisien. Sebagaimana diungkapkan bahwa pada dasarnya kurikulum yang terdapat pada kelas unggulan itu sama dengan kelas reguler, hanya saja pada kelas unggulan ada penambahan jam pelajaran dan penambahan jumlah mata peajaran, seperti: hari Senin sampai dengan hari Kamis setelah shalat Ashar ada bimbingan mental yang dibimbing oleh guru. Pada hari Jumat sampai dengan hari Sabtu itu ekstrakurikuler yang dipilih siswa masing-masing sesuai dengan bakat dan minat mereka masing-masing, seperti: bahasa (english club, dll), seni (drum band, tari, membuat kreatifitas dari barang bekas, dll), olahraga (futsal, badminton, volli, basket, hoki, tennis, dll), bidang keagamaan (kaligrafi, pembinaan Qori'-Qori'ah, dakwah, peyelenggaraan jenazah, dll). Sistem belajar mengajar di kelas unggulan yaitu Setiap pagi sebelum belajar seluruh siswa diwajibkan membaca Alquran 10 menit, kemudian menggunakan fasilitas yang ada di dalam kelas, seperti: Infokus, DVD, Komputer/Laptop, dan perpustakaan mini.

Begitu juga diungkapkan kurikulum antara kelas unggul dengan kelas reguler sama, hanya bedanya pada unggulan itu ada les sore (bimbingan belajar) di sore hari yaitu pada jam 14.0017.0o dengan tutornya guru itu sendiri tetapi di bawah naungan bimbel yaitu Prima Quality. Yang di bimbingan belajarkan itu adalah yang masuk pada atau yang berkaitan dengan UAS. Jam mata pelajaran antara reguler dengan unggulan itu sama, hanya saja pada unggulan ada penambahan jam pelajaran. Tenaga pengajarnya sama, cuma fasilitasnya berbeda. Pada kelas unggul itu mereka mendapatkan bangku sendiri-sendiri, ruangan dilengkapi Air Conditioner, ada komputer, perpustakaan, gurunya menggunakan IT (information and technology).

\section{Pengawasan Program Kelas Unggulan}

Terkait dengan pelaksanaan proses pembelajaran terutama pada pelaksanaan program kelas unggulan juga dibutuhkannya pengawasan pada proses belajar mengajar pada program kelas 
unggulan, hal ini sebagaimana diungkapkan bahwa pengawasan di kelas unggulan juga tidak jauh berbeda hanya saja ada yang khusus mengkoordinir kelas unggulan tersebut yang pastinya koordinator kelas unggulan.

Disamping keterangan kepala madrasah di atas, peneliti juga menanyakan kepada informan yang lainnya, sebagaimana juga diungkapkan bahwa pengawasan kelas unggul dengan kelas reguler itu berbeda, sistem pengawasan kelas unggulan itu ada piketnya: WKM (Wakil Kepala Madrasah), Bimbingan Konseling, Koordinator Kelas Unggul. (Salmah Yusri)

Berdasarkan hasil wawancara dapat disimpulkan bahwa pengawasan yang dilakukan pihak madrasah kepada kelas unggul berbeda, kelas unggul ada koordinator juga ada piket untuk mengawas kelas unggul.

\section{Evaluasi Program Kelas Unggulan}

Kelas unggulan di MTs N 2 Medan tidak cukup hanya didukung oleh perencanaan, pengorganisasian, pelaksanaan serta pengawasan. Akan tetapi harus juga diimbangi dengan evaluasi hasil pembelajaran. Berdasarkan hasil evaluasi program kelas unggulan diperoleh bahwa; dilaksanakannya UTS (Ujian Tengah Semester), UAS (Ujian Akhir Semester), kelas unggul juga memiliki raport bulanan, yang mana raport bulanan itu diserahkan (ditunjukkan) ke orang tua siswa kelas unggulan dan ditandatangani oleh orang tua/wali, dan juga memiliki kartu tahfiz. Juga ada penilaian tersendiri terutama dari akhlak siswa, daftar kehadiran tepat waktu, keaktifan di kelas, dan lain-lain.

Hal serupa diungkapkan juga oleh koordinator kelas unggulan bahwa evaluasi yang dilakukan sekolah yaitu adanya nilai bulanan, nilai ujian tengah semester dan ujian akhir semester, dan nilai try out (yang dilakukan Satu bulan sekali oleh kelas unggul, mengadakan Try Out dari bimbingan belajar Prima Quality).

Sebagaimana hasil wawancara terhadap beberapa informan tersebut maka dapat diambil kesimpulan bahwa evaluasi pembelajaran pada kelas unggulan di MTs N 2 Medan berbeda dengan kelas reguler. Adanya kerjasama dengan bimbingan belajar dan mental dengan Prima Quality, dan menggunakan teknik-teknik tes yang lain yang dapat meningkatkan produktivitas alumni atau tamatan program kelas unggulan di MTs N 2 Medan.

Dari hasil penelitian yang telah diuraikan di atas, diketahui bahwa:

a. Perencanaan program kelas unggulan di MTs N 2 Medan didasari adanya keinginan atau kebijakan Kepala Kantor Wilayah Kementerian Agama yaitu menginginkan adanya kelas unggulan di beberapa madrasah khususnya di propinsi Sumatera Utara. Perencanaan tersebut dilatarbelakangi juga agar dapat melihat potensi-potensi atau bakat siswa yang terbaik di MTs N 2 Medan, juga untuk dapat meningkatkan kualitas pendidikan di madrasah dan peningkatan sumber daya manusia (SDM).

b. Pengorganisasian kelas unggul di MTs $\mathrm{N} 2$ Medan dilakukan dengan dibentuknya/diadakannya koordinator khusus yaitu koordinator progam kelas unggul, dilakukan agar dapat tercapainya proses kegiatan belajar serta demi lancarnya proses pengadministrasian.

c. Pelaksanaan program kelas unggulan di MTs N 2 Medan, dilaksanakannya programprogram tambahan seperti: penambahan jam pelajaran, dan penambahan mata pelajaran yang berkaitan dengan UAS, serta adanya penambahan seperti bimbingan belajar dan bimbingan mental yang bekerja sama dengan Prima Quality.

d. Pengawasan pada program kelas unggul di MTs N 2 Medan dilakukan dengan cara bekerja sama dengan antara kepala madrasah dengan koordinator kelas unggulan. Seperti dibentuknya jadwal piket yang sistematis, dan yang lain yang menyangkut demi lancarnya proses pembelajaran.

e. Evaluasi pada program kelas unggulan di MTs N 2 Medan dilakukan dengan adanya nilainilai try out (satu bulan sekali) yang dilakukan oleh bimbingan belajar bekerja sama 
dengan pihak madrasah yang pastinya. Diadakannya teknik-teknik test lainnya yaitu UTS (ujian tengah semester), US (ujian semester).

Hasil penelitian yang ditemukan sejalan sebagaimana yang disampaikan oleh Syafaruddin dan Mesiono (2006) bahwa Sekolah unggul (excellent school) adalah sekolah yang semua sumber dayanya, proses dan manajemennya mampu menghasilkan lulusan yang memiliki mutu dan kualitas tinggi dibandingkan dengan sekolah lainnya dalam jenis, jenjang dan program yang sama atau berbeda. Perihal tersebut juga senada yang disampaikan oleh Susan Albers Moharman (1994) bahwa sebutan sekolah unggulan itu sendiri memang dirasa kurang tepat. Kata "unggul" (excellence) menyiratkan adanya superioritas dibanding dengan yang lain. Kata ini menunjukkan adanya "kesombongan" intelektual yang sengaja ditanamkan di lingkungan sekolah. Di negaranegara maju, untuk menunjukkan sekolah yang baik tidak menggunakan kata unggul (excellence) melainkan effective, develop, accelerate, dan essential.

Tegasnya sekolah unggul adalah sekolah yang mampu memproses pembelajaran siswa secara efektif sehingga menghasilkan lulusan yang bermutu unggul. Maksudnya apakah masukan siswa berasal dari siswa berprestasi maupun masukan siswa yang biasa-biasa saja. Justru yang paling unggul adalah sekolah yang menghasilkan siswa yang bermutu unggul dari masukan siswa yang awalnya biasa-biasa saja. Artinya manajemen dan kepemimpinan sekolah sudah berhasil menciptakan iklim pembelajaran yang unggul sehingga menghasilkan lulusan yang unggul secara akademik dan non akademik.

Dari pemaparan di atas setidaknya kita dapat melihat ciri atau tipe sekolah unggul dari praktiknya selama ini, antara lain:

Pertama; sekolah yang memiliki input siswa unggul, meskipun proses pembelajaran tidak luar biasa, maka lulusannya tetap bisa menjadi unggul. Keunggulan merupakan bawaan siswa yang masuk ke sekolah unggul, apalagi bila fasilitas dan pembelajarannya memang unggul.

Kedua; sekolah yang memiliki fasilitas lengkap dan unggul, sehingga pembiayaan jauh berbeda dengan sekolah lain yang tidak memiliki fasilitas lengkap dan mahal (lapangan olah raga lengkap, kelas ber-AC, asrama ber-AC, media pengajaran yang canggih/audio-visual, pembelajaran berbasis jaringan, dan fasilitas lain yang serba mahal. Dengan iklim sekolah seperti ini, daya tahan siswa dalam belajara bisa lebih lama, guru-guru pilihan, rasio guru dngan murid benar-benar standar, dan harapan prestasi belajar lebih tinggi.

Ketiga; sekolah unggul jenis ini penekanan pada iklim belajar yang positif di lingkungan sekolah. Di Amerika justru sekolah unggul tipe ini yang diterima sebagai sekolah unggul, karena mampu memproses siswa (input) dari bermutu rendah waktu masuk sekolah menjadi lulusan yang bermutu tinggi (output).

Patut juga kita cermati bahwa sebutan sekolah unggulan itu sendiri memang dirasa kurang tepat. Kata "unggul" (excellence) menyiratkan adanya superioritas dibanding dengan yang lain. Kata ini menunjukkan adanya "kesombongan" intelektual yang sengaja ditanamkan di lingkungan sekolah. Di negara-negara maju, untuk menunjukkan sekolah yang baik tidak menggunakan kata unggul (excellence) melainkan effective, develop, accelerate, dan essential (Susan Albers Mohrman, 1994).

\section{SIMPULAN}

Berdasarkan hasil penelitian yang telah dilaksanakan dapat disimpulkan bahwa pelaksanaan manajemen pendidikan program kelas unggulan di MTs Negeri 2 Medan dibatasi dalam ruang lingkup kajian perencanaan, pengorganisasian, pelaksanaan dan evaluasi program kelas unggulan dalam bidang akademik dan pengetahuan yang bertujuan melahirkan alumni dan lulusan serta bibit bibit unggul dan berkualitas dan memiliki segudang prestasi dimasa depan, baik di bidang akademik maupun di bidang non akademik. Untuk menciptakan sekolah unggul, diperlukan modal kemampuan manajerial dan kepemimpinan serta strategi yang jelas, kuat dan terkontrol, agar dapat menghasilkan lulusan dan alumni yang berkeunggulan. MTs Negeri 2 Medan sudah melakukan atau melaksanakan serta menciptakan kelas unggul yang menjadi salah 
satu daya tarik dari sekolah tersebut. Dimana dalam program kelas unggul tersebut diupayakan sebaik-baik mungkin. Mulai dari perencaannya, pelaksanaan, pengorganisasian, pengawasan serta evaluasi program kelas unggulan yang ada di MTsNegeri 2 Medan.

Para lulusan dan alumni MTs Negeri 2 Medan yang berkualitas serta memiliki skill dalam bidang ilmu pengetahuan agama, pengetahuan umum dan teknologi dapat berkiprah dalam masyarakat dan memberikan kontribusi positif dalam pengembangan pendidikan dan pengetahuan agama, bidang tahfiz Alquran, pengajaran bahasa asing Arab dan Inggris dan pengetahuan lainnya dalam lingkungan masyarakat tempat tinggal mereka, dan pada akhirnya berimplikasi terhadap kemajuan masyarakat dalam bidang ilmu agama, pengetahuan dan teknologi.

Penelitian ini memiliki keterbatasan waktu dalam mengkaji lebih dalam lagi aspek-aspek yang paling dominan menjadi keberhasilan penerapan manajemen dalam program kelas unggulan. Diharapkan ini bisa menjadi kajian selanjutnya bagi peneliti lain yang juga ingin melakukan kajian pada program kelas unggulan.

\section{DAFTAR PUSTAKA}

Appley, A. L, Lee,O,L. (2010). Pengantar Manajemen. Jakarta. Salemba Empat.

Fattah, Nanang. (2008). Landasan Manajemen Pendidikan. Bandung: Remaja Rosdakarya.

Gamage, D. T., Nichol. S., K. P., (2003). Leardership and Management in Education. Hongkong:

The Chinese University Press.

Hanun, S. (2016). Membangun Citra Madrasah Melalui Program Kelas Unggulan di MTs Negeri 2 BandarLampung.https://jurnaledukasikemenag.org/index.php/edukasi/article/view/9.

Kartiningsih, S. (2014). Manajemen Kelas Unggulan di Madrasah (studi kasus di madrasah Tsanawiyah.) https://jurnal.untan.ac.id/index.php/jpdpb/article/view/6248/7179

Lawler III, Edward. E., Christopher G. W. (2006). Built to Change: How to Achieve Sustained Organizational Effectiveness. San Francisco: Jossey Bass.

McMillan, James H., Sally S. (2001). Research in Education: A Conseptual Introduction. New York: Longman.

Moedijarto, (2006). Sekolah Unggul. Jakarta: Duta Graha Pustaka.

Mohrman, Susan A., et.al. (1994). School based management: Organizing for High Performance. San Francisco.

Moleong, L. J, (2010). Metodologi Penelitian Kualitatif; Edisi Revisi. Bandung: PT Remaja Rosdakarya, 2010.

Mukhtar, Rusmini., Samsu. (2003). Sekolah Berprestasi. Jakarta: Nimas Multma.

Nurmawati, Syafaruddin. (2011). Pengelolaan Pendidikan. Medan: Perdana Publishing.

Rachman, Taufiq. (2011). Sistem Analisis Administrasi dan Manajemen: Suatu Tinjauan Teoritis dan Praktis. Medan: Perdana Publishing.

Saefullah, U. (2012). Manajemen Pendidikan Islam. Bandung: CV. Pustaka Setia.

Saran, R., Verron T. (1990). Research in Education Management and Policy: Retrospect and Prospect. London: The Falmer Press.

Shiberg, Arthur., et al. (1997). Practicing Leardership. Canada: John Willey \& Sons, Inc.

Sitorus, Masganti. (2011). Metodologi Penelitian Pendidikan Islam. Medan: Perdana Mulya Sarana.

Sudjana. (2000). Manajemen Program Pendidikan: Untuk Pendidikan Luar Sekolah dan Pengembangan Sumber Daya Manusia. Bandung: Falah Production.

Sugiyono. (2008). Metode Penelitian Kuantitatif dan $R$ \& D. Bandung: Penerbit Alfabeta, 2008.

Surachman, Winarno, dalam St. Sularto, ed, Pendidikan Nasional: Strategi dan Tragedi. Jakarta: Gramedia.

Surachman, Winarno. (1992). Dasar dan Teknik Research. Bandung: Remaja Rosdakarya.

Syafaruddin. (2005). Manajemen Lembaga Pendidikan Islam. Jakarta: Ciputat Press.

Syafaruddin. (2009).Pendidikan \& Transformasi Sosial. Bandung: Citapustaka Media Perintis.

Syafaruddin, Mesiono. (2006). Pendidikan Bermutu Unggul. Bandung: Citapustaka Media.

Wati, Z. R. A., Trihantoyo, S. (2020). Strategi Pengelolaan Kelas Unggulan dalam Meningkatkan Prestasi Belajar Siswa, Tsanawiyah, https://journal.unesa.ac.id/index.php/idmp/article/ view/10605. 